\title{
SMEs and Entrepreneurial Finance in OECD Countries: Good Practice and Lessons Learned
}

\author{
Yongqiang Li \\ Victoria University, Australia
}

\begin{abstract}
This paper will review the small and medium-sized enterprises (SMEs) and entrepreneurship finance policies and practice in OECD countries by gleaning the best evidence available. The paper treated SME financing as a governance issue and applied the governance analytical techniques. The study integrated both the supply and demand sides of the SME finance in the analysis of SME access to finance, credit reporting, alternative financing options, financing innovation and the situation of market failure. The review finds that Australia has fallen far behind the other OECD countries in making efforts to understand the demands of small business financing and hence failed to respond to such unmet needs due to lack of solid evidence. Good practice and lessons learned summarised from the review may shed light on the policy development for SME and entrepreneurship finance in Australia in the future.
\end{abstract}

\section{Key words:}

Small business financing, access to financing, good practice, lessons learned

"Debt and equity are treated not mainly as alternative financial instruments, but rather as alternative governance structures. Debt governance works mainly out of rules, while equity governance allows much greater discretion. ... A combined treatment of corporate finance and corporate governance is ... proposed."

--- Williamson (1988, p.567)

\section{Introduction}

SMEs are an integral part of the modern economy. This section first defined the key terms of Small and Medium-sized Enterprises (SMEs) and SME financing. Then the SME financing issue has been identified as a governance issue, hence analytical frameworks on governance can be applied to the analysis.

Small and medium-sized enterprises: a definition

There are hundreds of definitions about Small and Medium-sized Enterprises (SMEs) globally (Ayyagari et al. 2007). For the purpose of the study, here the OECD definition is used. The OECD (2014) defines SME as a firm which employs less than 199 employees, excluding those in the

Copyright (C) 2015 Victoria University. This document has been published as part of the Journal Law and, Governance in both online and print formats. Educational and non-profit institutions are granted a non-exclusive licence to utilise this document in whole or in part for personal or classroom use without fee, provided that correct attribution and citation are made and this copyright statement is reproduced. Any other usage is prohibited without the express permission of the publisher. financial service industry and excluding non-employing businesses. The abovementioned OECD definition has been used consistently for data collection in OECD Countries, including Australia, as of 2011. However, Australia did not participate in previous data collections. 
SME financing: a definition

OECD (2013) defines SME financing as such activities that SMEs use to obtain and secure sources of funds for the purpose of business operation and expansion.

SMEs face numerous barriers to access finance, some of which include the following:

- Resource constraints

- Lack of collateral

- Lack of financial expertise

- Lack of knowledge about the financial market

- Limited products available for SME and entrepreneurial financing

SME financing: a governance issue

This study proposes the SME financing is a governance issue. The academic discussions around SME financing date back to the milestone which erected Corporate Governance as a discipline, the Jensen and Meckling's paper (1976, p.305). Their paper centres on the discussion of business financing and

“... investigate the nature of the agency costs generated by the existence of debt and outside equity, ... analysis of the factors influencing the creation and issuance of debt and equity claims is a special case of the supply side of the completeness of markets problem. "'

The view of business financing as a governance mechanism has been reinforced by Williamson (1988, p.567). He argues that

"Debt and equity are treated not mainly as alternative financial instruments, but rather as alternative governance structures. Debt governance works mainly out of rules, while equity governance allows much greater discretion. ... A combined treatment of corporate finance and corporate governance is ... proposed."

Given that the SME financing is a governance issue, the techniques of governance analysis can be used for SME financing. Such analyses include exploring market mechanisms and the government intervention, which will be discussed in the analytical framework below.

\section{Analytical Framework}

Putting OECD countries in the centre of the study and treating SME financing as a governance mechanism, the analysis starts with the assumption that the market functions well and the SMEs have access to the market and then moves onto the scenario when the market fails. The analysis unveils the real problem in SME financing or lack thereof.

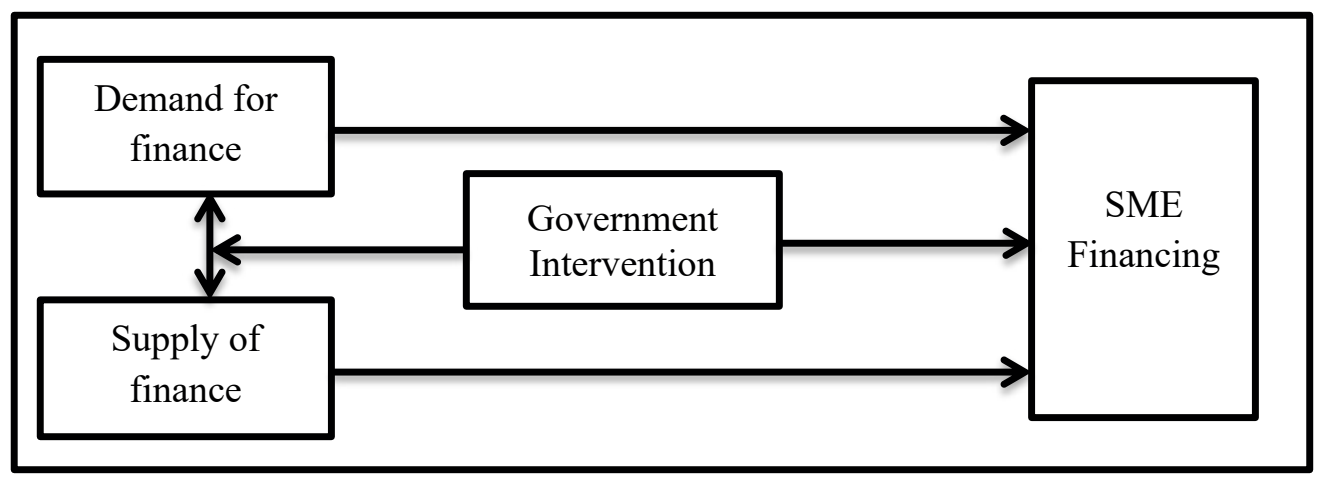

Figure 1 Analytical framework for SME financing 
The analytical framework for SME financing is provided in Figure 1. From the market economy perspective, the demand and supply of finance determines the SME financing. However, due to information asymmetry between the lenders and the borrowers, the moral hazard during the borrowing process and that the market is imperfect, government intervention should be a necessary component of the governance system for small business financing (Fig. 1).

SME financing: A market economy analysis

Small business financing can be analysed using supply- and demand-side components, that include incentives, costs of financing, risks and information (World Bank 1999). The SMEs are the borrowers, while the financial institutions are the lenders (Table 1).

For lenders, the incentives for SME financing are mainly the interest rate on loans and to expand their client bases. Borrows would normally use additional financing as the means to expand their sales capacity which is largely determined by market demand and competition.

Table 1 Typology of market economy mechanisms

\begin{tabular}{lll}
\hline \multicolumn{1}{c}{ Factor } & \multicolumn{1}{c}{ Lender - Supply } & \multicolumn{1}{c}{ Borrower - Demand } \\
1. Incentives & $\begin{array}{l}\text { Interest rate on loan; } \\
\text { building client base }\end{array}$ & $\begin{array}{l}\text { Opportunity to expand sales } \\
\text { capacity which is determined by } \\
\text { 2. Costs }\end{array}$ \\
& $\begin{array}{l}\text { Time spent screening, monitoring } \\
\text { and ensuring repayment of loans } \\
\text { interest rate; } \\
\text { time spent in applying for credit }\end{array}$ \\
3. Risks & $\begin{array}{l}\text { Arrears or default if borrower is } \\
\text { unable or unwilling to repay }\end{array}$ & $\begin{array}{l}\text { Inability to repay loan may lead to } \\
\text { bankruptcy }\end{array}$ \\
& $\begin{array}{l}\text { Inadequate knowledge of } \\
\text { customer's reputation and business } \\
\text { prospects }\end{array}$ & $\begin{array}{l}\text { Inadequate knowledge about dealing } \\
\text { with banks or availability of credit }\end{array}$ \\
Difficulty of appraising small & $\begin{array}{l}\text { lack of adequate financial accounts on } \\
\text { the firm } \\
\text { loans }\end{array}$ & $\begin{array}{l}\text { uncertain about ability to increase } \\
\text { sales enough to repay loan }\end{array}$ \\
& &
\end{tabular}

The main cost for lenders are transaction costs, monitoring costs and enforcement costs which include the time spent on screening applications, monitoring of the SME loans and ensuring repayment of loans. The costs for SMEs are mainly interest and the time spent on preparing the loan applications.

Lenders may face the risks of arrears or default if borrower is unable or unwilling to repay given that they have inadequate knowledge of customer's reputation and business prospects. The SMEs which are unable to repay the loans may face bankruptcy. Moreover, the SMEs may have little knowledge about dealing with banks and the availability of credits.

The complexity facing lenders are mainly the difficulty of appraising SME loans. While for SMEs, the lack of collateral and tracked record of financial history and uncertainty about their market conditions creates challenges for their capacity to repay the loans.

The OECD (2014) report finds that the gap between the supply and demand of SME financing is widening year by year (Fig. 2). The widening gap between the supply and demand of SME finance is the actual problem, which cannot be adjusted by market mechanism. Hence government intervention is required. 


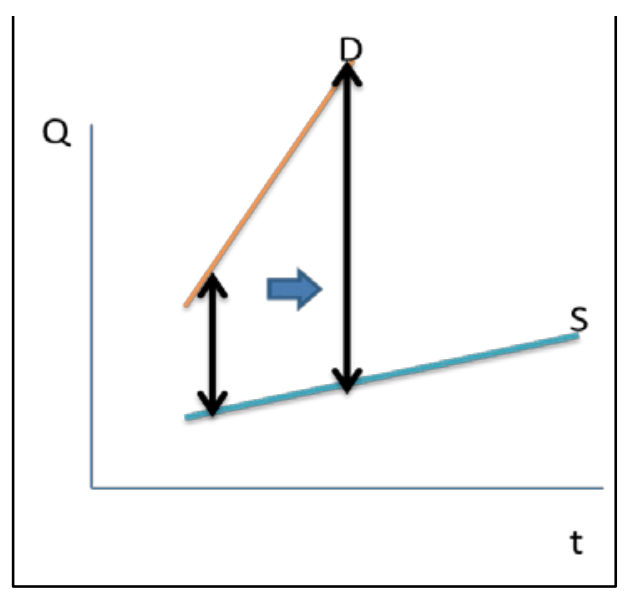

Figure 2 The widening SME financing gaps

SME Financing: Market Failure

The market failure for SME financing is mainly due to a few factors, such as SMEs' lack of collateral and lack of credit history, high screening and monitoring cost for SME loans, the oligopolistic lender market structure, and the technological innovations in banking and finance. Unless the financial and capital markets are competitive enough to address the SMEs' financing needs, provided that the transaction and monitoring costs can be substantially reduced, governments and SMEs should seek alternative financing options as a complement to the traditional banking instruments. Other OECD countries have made some effort to provide alternative mechanisms, while Australia is falling behind in such SME financing innovations. Below summarises some good practices and lessons learned from the other OECD countries.

\section{Good Practices of the Other OECD Countries}

There are six major alternatives to bank loans as financing options to SMEs, namely Mezzanine finance, Credit (SME loan) Guarantee, Peer-to-Peer Lending, particularly Equity-based Crowdfunding, Project Funding, Government Direct Assistance/Grants, Preferable Tax Treatments (Cumming 2012).

The Mezzanine finance is a combination of several debt and equity instruments in a single investment vehicle. In case of bankruptcy, mezzanine investors have higher priority than equity investors but lower priority than other creditors. Practically, Mezzanine finance requires SMEs to pay interest promptly and pay additional payments in the future which are contingent on the financial performance of the firm (OECD 2014). The Mezzanine finance is mainly a private ordering approach which balances the incentives, costs, information and risks as shown in Table 1.

The Credit Guarantee is a direct government or semi-government support to the SMEs to compensate for their lack of collateral and lack of track record of credit history.

Peer-to-Peer lending is an emerging technique which matches the financing needs from the SMEs at large and the supply of finance from the general public. A particular form which has attracted much attention for most of the governments around the world is equity-based crowdfunding. However, the development is still at its early stage. Though America passed the JOBS ACT in 2013 to facilitate crowdfunding, the take up is relatively low.

Project funding takes a different approach, rather than focusing on the SMEs, the funding decisions are normally centred on the projects. This approach is particularly useful for certain industries such as manufacturing and real estate, in which the projects are often long term and due to the nature of the 
risks it is not that attractive to investors. Project funding mainly addresses the risk and information issues.

Table 2 Government policies of SME financing in OECD Countries

\begin{tabular}{l}
\hline Policy response \\
\hline Government loan guarantees \\
Special guarantees and loans for start ups \\
Government export guarantees, trade credit
\end{tabular}

Direct lending to SMEs

Subsidized interest rates

Venture capital, equity funding, business angel support

SME banks

Business advice, consultancy

Tax exemptions, deferments

Credit mediation/ review/code of conduct

Bank targets for SME lending, negative interest rates for deposits at central bank
Countries

Austria, Belgium, Canada, Chile, Colombia, Czech

Republic Denmark,

Finland, France, Greece, Hungary, Ireland, Israel, Italy, Korea,

Mexico, the Netherlands, Norway, Portugal, Russian Federation,

Serbia, Slovak Republic, Slovenia, Spain, Sweden, Switzerland,

Thailand, Turkey, United Kingdom, United States Austria, Canada, Denmark, Mexico, the Netherlands, Serbia, United Kingdom

Austria, Belgium, Canada, Colombia, Czech Republic,

Denmark,

Finland, Hungary, Korea, the Netherlands, New Zealand, Spain, Sweden

Austria, Belgium, Canada, Chile, Colombia, Czech Republic, Finland,

France, Greece, Hungary, Ireland, Israel, Korea, Norway, Portugal,

Serbia, Slovak Republic, Slovenia, Spain, Sweden, Turkey, United Kingdom

Austria, Greece, Hungary, Portugal, Russian Federation, Spain,

Turkey, United Kingdom

Austria, Belgium, Canada, Chile, Denmark, Finland, France, Greece,

Hungary, Ireland, Israel, Mexico, the Netherlands, New Zealand,

Norway, Portugal, Spain, Sweden, Turkey, United Kingdom

Czech Republic, France, Portugal, Russian Federation, United Kingdom

Austria, Colombia, Denmark, Finland, the Netherlands, New Zealand,

Sweden

Belgium, Finland, Italy, New Zealand, Norway, Spain, Sweden, Turkey

Belgium, France, Ireland, New Zealand, Spain

Ireland, Denmark

Central Bank funding to banks dependent on net lending rate

United Kingdom

Source: OECD (2014) p. 41

Government Direct Assistance/Grants include policies such as government loan guarantees, government export guarantees, trade credit, direct lending to SMEs, government procurement (Table 2).

Preferable Tax Treatments are tax benefits targeting at particular industry or business groups, such as exporting SMEs and start-ups (Table 2). 


\section{Lessons Learned from the Other OECD Countries}

The review also draws some lessons from the policy reforms in SME financing, in OECD countries related to the poor competition of SME banking lack of data and the quality of data, as well as consistent definitions of SMEs.

SME financing or lack thereof in OECD countries has suffered from lack of competition for SME lending. Denmark's central bank has introduced negative interest rates for bank deposits at the central bank to encourage commercial lending in the real economy (OECD 2014).

Though the OECD made the joint efforts to collect data on the supply and demand of SME finance, lack of data is still a major issue given that a great number of SMEs are excluded from the formal financial system. Even for countries where data may be available, different government departments are reluctant to share their data.

The quality of data and definition of SMEs are technical issues challenging the SME financing reforms. In particular, at this stage, all the OECD data excludes non-employing SMEs from the data collection. It is widely acknowledged that such omission is a significant one and will have tremendous impacts on the design and evaluation of policy options.

\section{Implications and Future Work}

The review of the SME financing policies in the OECD countries found that

- The SMEs are disadvantaged in accessing finance. Government should intervene.

- There is no quick fix for the SMEs financing problem.

- There is always more than one option available from good practice of the other OECD countries.

- Australia has to take prudential steps to catch up with the other OECD countries in providing more and easier loans to SMEs.

Hence, future research should endeavor to establish the evidence base for various options of SME financing. In addition, Australia should join the other OECD Countries in SME finance related data collection and analysis. Future work should also attempt to resolve the data quality and SME definition issues.

\section{Reference}

Ayyagari, M., Beck, T., \& Demirguc-Kunt, A. (2007). Small and medium enterprises across the globe. Small Business Economics, 29(4), pp. 415-434.

Cumming, D. (Ed.). (2012). The Oxford handbook of entrepreneurial finance. Oxford University Press.

Jensen, M. and W. Meckling (1976) Theory of the Firm: Managerial Behavior, Agency Costs and Ownership Structure, Journal of Financial Economics, Vol. 3, No. 4, pp. 305-360.

Modigliani, F. and M Miller (1958) The Cost of Capital, Corporation Finance and the Theory of Investment. American Economic Review, Vol. 48, No. 3. pp. 261-297.

Organisation of Economic Cooperation and Development (OECD) Financing SMEs and Entrepreneurs 2014: An OECD Scorecard. OECD Publishing. Doi: 10.1787/fin_sme_ent-2014-en.

Williamson, O. (1988) Corporate Finance and Corporate Governance, Journal of Finance, Vol. XLIII, No. 3. pp. 567-591. 